\title{
Referaat
}

\section{Mag ik even uitpraten?}

Langewitz W, Denz M, Keller A, Kiss A, Rüttiman S, Wössmer B. Spontaneous talking time at start of consultation in outpatient clinic: cohort study. BMJ 2002;325:682-3.

In 1984 hebben Howard Beckman en Richard Frankel $^{1}$ een onderzoek verricht dat sindsdien door communicatievaardigheden specialisten veelvuldig is aangehaald. Zij analyseerden 74 bezoeken aan spreekuren van een eerstelijns interne geneeskunde praktijk. Zij constateerden dat in slechts 17 (23\%) van deze bezoeken de patiënt de gelegenheid kreeg zijn/haar opening ongehinderd te voltooien. In 51 (69\%) van de bezoeken onderbrak de arts de eerste zinnen van de patiënt, en richtte hij zijn vragen op een specifiek onderwerp. In 1 van deze 51 consulten kreeg de patiënt later nog de gelegenheid zijn opening af te maken. In $6(8 \%)$ herhalingsbezoeken werd überhaupt niet gevraagd naar (eventuele andere) redenen van de komst. Eén van de conclusies van dit onderzoek, namelijk dat "artsen hun patiënten onderbreken na gemiddeld 18 seconden van de openingszin", wordt vaak aangehaald.

In 1999 werd dit onderzoek bij huisartsconsulten gerepliceerd, ${ }^{2}$ zij het met een eleganter onderzoeksdesign. Intussen hadden de auteurs het woord 'onderbreken' (to interrupt) vervangen door 'bijsturen' (to redirect), om meer recht te doen aan wat er feitelijk gebeurde. Dit keer werd de opening van de patiënt in 74 van de 199 gevallen (28\%) afgemaakt. Artsen stuurden de opening bij na een gemiddelde tijd van 23 seconden. De patiënten die hun opening wel af konden maken, hadden gemiddeld 6 seconden meer nodig dan degenen die tijdens hun opening bijgestuurd werden. Na bijsturing werd de opening zelden afgemaakt.

In het British Medical Journal van 28 september 2002 werd een onderzoek gerapporteerd dat bijna alle Nederlandse dagbladen gehaald heeft. Het vormde een goede aanvulling op de boven aangehaalde artikelen. Het Zwit- serse team van Wolf Langewitz vroeg artsen van een polikliniek interne geneeskunde om onopvallend een stopwatch aan te zetten bij het begin van een consult, en deze opnieuw in te drukken als de patiënt aangaf dat de dokter het gesprek nu wel kon overnemen. De artsen hadden een training van een uur gekregen in actief luisteren. Hen werd gevraagd geen vragen te stellen in deze eerste fase van het consult, maar ze mochten onderbreken als de patiënt vijf minuten onafgebroken zou doorpraten. De spontane spreekduur van 335 patiënten in gesprek met 14 artsen werd zo vastgelegd. De gemiddelde spontane spreekduur was iets langer dan anderhalve minuut. 258 Patiënten (78\%) hadden twee minuten nodig om hun opening af te ronden. In alle gevallen vonden de artsen de gegeven informatie belangrijk. De enige artsvariabele die verschil maakte op de spontane spreektijd was leeftijd: oudere artsen gaven hun patiënten langer de tijd. Dit onderzoek werd uitgevoerd in een tertiair ziekenhuis, met gemiddeld genomen 'moeilijke' patiënten met ingewikkelde ziektegeschiedenissen (Langewitz, et al., 2002).

Het is verleidelijk om hieruit te concluderen dat vijftien jaar communicatievaardigheidstraining een netto toename van ononderbroken spreektijd van de patiënt heeft opgeleverd van vijf seconden. Als die toename lijnrecht doorzet kan $80 \%$ van de patiënten zo tegen 2018 uitpraten.

De groep van Beckman erkende dat de tijd van artsen beperkt is. Bovendien is het wellicht niet altijd wenselijk of nodig om dogmatisch een uitvoerige opsomming van de zorgen van de patiënt te moeten vernemen. Patiënten willen soms emotioneel geladen onderwerpen uitstellen totdat zij de kat uit de boom gekeken hebben, of totdat de arts er zelf naar vraagt. Debra Roter ${ }^{3}$ en haar groep hebben echter in 1995 al aangetoond dat ervaren artsen niet meer tijd nodig hebben om een gesprek te voeren waarin de patiënt kan uitpraten, dus 'tijd' is geen sterk argument om het niet te doen. 'Luisteren naar patiënten' is een vaardigheid 
die geleerd kan worden. In het licht van de winst die met deze vaardigheid te behalen is, verdient het aanbeveling aankomende hulpverleners hierin goed te (blijven) trainen.

\section{Literatuur}

1. Beckman HB, Frankel RM. The effect of physician behavior on the collection of data. Ann Intern Med 1984;101:692-6.

2. Marvel MK, Epstein RM, Flowers K, Beckman HB. Soliciting the patient's agenda. Have we improved? JAMA 1999;281(3):283-7.

3. Roter DL, Hall JA, Kern DE, Barker LR, Cloe KA, Roca RP. Improving physicians' interviewing skills and reducing patients' emotional distress. Arch Intern Med 1995;155:1877-84.

Jan van Dalen

Maastricht 